\title{
A INSERÇÃO DAS ÁREAS VERDES NAS UNIDADES AMBIENTAIS DA CIDADE DO RECIFE: UMA REFLEXÃO SOBRE A CONSERVAÇÃO DA GEODIVERSIDADE NO ESPAÇO URBANO
}

\author{
THE INSERTION OF GREEN AREAS IN THE ENVIRONMENTAL UNITS OF THE CITY OF RECIFE: A REFLECTION ON THE \\ CONSERVATION OF GEODIVERSITY IN AN URBAN SPACE
}

\section{LA INSERCIÓN DE ÁREAS VERDES EN LAS UNIDADES AMBIENTALES DE LA CIUDAD DE RECIFE: UNA REFLEXIÓN SOBRE LA CONSERVACIÓN DE LA GEODIVERSIDAD EN EL ESPACIO URBANO}

\begin{abstract}
RESUMO
Introdução: A necessidade de preservação da geodiversidade assumiu um papel de destaque nas ciências geográficas e da terra ao longo da última década. Esta questão é de particular interesse quando se consideram as aglomerações urbanas, sedes de regiões metropolitanas como Recife. Objetivo: A pesquisa buscou aferir como as Unidades Ambientais do Recife estão representadas nas áreas verdes públicas do município, e como essas têm servido à multiplicidade de usos que se esperam delas junto à população. Resultados: A maioria dos usuários dos parques entrevistada afirma que a quantidade de áreas verdes existentes na cidade é suficiente, no entanto apontam para problemas no estado de conservação, acessibilidade entre os diversos bairros e unidades ambientais que integram o município. Conclusão: $\mathrm{O}$ trabalho demonstra a desigualdade com que parques e áreas verdes públicas no Recife são tratadas por parte dos órgãos públicos competentes, além de apontar para o sentimento dos seus usuários em relação à situação atual dessas áreas no tocante à sua manutenção, preservação e oferta pública de lazer.
\end{abstract}

Palavras-chave: Áreas Verdes Urbanas. Áreas Verdes Públicas. Unidades Ambientais. Geodiversidade. Geoconservação.

\begin{abstract}
Introduction: The need to preserve geodiversity has gained a prominent role in geographic and earth sciences over the past decade. This issue is of particular interest when considering large urban agglomerations, which are the seat of metropolitan regions such as Recife. Objective: The research seeks to assess how the environmental units of Recife are represented in the green public areas of the city, and how these have been serving the multiplicity of uses the general public expects of them. Results: The majority of park users interviewed asserted that the number is of green public areas is satisfactory, notwithstanding they pointed to problems concerning the state of conservation of accessibility among the neighborhoods and environmental units of the municipality. Conclusion: The work demonstrates the inequality by means of which parks and green public areas are treated by the competent public organisms in Recife, as well as points out to the viewpoints of the users regarding the current state of such areas concerning their upkeeping, preservation and public offer of leisure.
\end{abstract}

Keywords: Urban green areas. Public green areas, Environmental Units, Geodiversity, Geoconservation.

\section{RESUMEN}

Introducción: La necesidad de preservar la geodiversidad ha ganado un papel destacado en las ciencias geográficas y de la tierra durante la última década. Este tema es de especial interés cuando se consideran las grandes aglomeraciones urbanas, que son la sede de regiones metropolitanas como Recife. Objetivo: La investigación buscó evaluar cómo las Unidades Ambientales de Recife están representadas en las áreas verdes públicas del municipio, y cómo estas han atendido la multiplicidad de usos que se espera de ellas por parte de la población. Resultados: La mayoría de los usuarios del parque entrevistados manifestaron que la cantidad de áreas verdes existentes en la ciudad es suficiente, sin embargo
Darta Elizabeth Guerra Corrêa Uchôa a (iD) Antonio Carlos de Barros Corrêa $^{\text {b }}$

a Universidade Federal de Pernambuco (UFPE), Recife, Pernambuco, Brasil

DOI: 10.12957/geouerj.2021.58769

Correpondência: antonio.correa@ufpe.br

Recebido em: 20 mar. 2020 Revisado em: 19 ago. 2019 Aceito em: 3 fev.2021 
señalan problemas en el estado de conservación, accesibilidad entre los distintos barrios y unidades ambientales que conforman el municipio. Conclusión: El trabajo demuestra la desigualdad mediante la cual los parques y áreas verdes públicas son tratados por los organismos públicos competentes en Recife, así como señala los puntos de vista de los usuarios sobre el estado actual de dichas áreas en cuanto a su mantenimiento, preservación y oferta pública de ocio.

Palavras-Clave: Areas Verdes Urbanas. Areas Verdes Públicas, Unidades Ambientales, Geodiversidad, Geoconservacion. 


\section{INTRODUÇÃO}

O Recife apresenta uma diversidade de unidades ambientais com fisionomias e funcionalidades próprias (CORREA, 2006, p. 86-102). Com base nesta assertiva, este estudo buscou identificar como os elementos que compõem a paisagem física do Recife encontram-se representados em suas áreas verdes de uso comum. A pesquisa buscou lançar luz sobre as razões de escolha das áreas privilegiadas pela presença das áreas verdes, bem como se essas dão conta da variedade de ambientes que compõem a base territorial física do Município.

Apesar do crescente interesse de geógrafos e geocientistas em geral acerca das questões da preservação da diversidade natural do planeta, em suas diversas escalas espaciais de expressão, ainda são poucos os estudos que versam sobre o papel e significado da geodiversidade no contexto da cidade. Esta questão é de particular interesse quando se consideram as grandes aglomerações urbanas, sedes de regiões metropolitanas como o Recife. Assim, o foco principal da pesquisa é identificar como a geodiversidade de ambientes físicos - aqui traduzida pelas Unidades Ambientais do Recife - está representada nas áreas verdes públicas no município, e como essas têm sido utilizadas como instrumento para a geoconservação, e ações que propiciem a multiplicidade de usos que se espera delas.

Parte-se do pressuposto que umas das funções precípuas das áreas verdes é propiciar aos citadinos contato com a natureza em suas variadas formas de expressão em determinado contexto urbano. Tal relação entre o morador da cidade e o espaço verde se reveste de singular importância para a aferição da qualidade de vida no contexto urbano, assim como das ações voltadas para a valorização e preservação do meio ambiente. Neste sentido, compreende-se que as áreas verdes além de propiciar espaço para o entretenimento, lazer e ócio ao ar livre, devem ter um significado diante das variadas expressões do mundo natural dentro da cidade, mesmo que essas sejam oriundas das escolhas estéticas e de renaturalização dessas áreas.

Gray (2004) afirma que geólogos e geomorfólogos iniciaram a utilização do termo geodiversidade em 1990 para descrever a natureza abiótica. No entanto, percebe-se que as ações de proteção patrimônio natural e caracterização da geodiversidade pouco se voltam aos contextos urbanos, onde os recortes designados como áreas verdes são de menor dimensão espacial ou quando já passaram por um processo intenso de transformação cultural e adaptação aos usos característicos do contexto urbano.

Diante desta chamada pela conservação e tomada de consciência frente às áreas verdes nas cidades, para além de atributos do desenho urbano, emerge a questão/problema que serviu de linha norteadora para esta pesquisa. Assim, indaga-se como as Unidades Ambientais do Recife estão representadas nas áreas verdes públicas do município, e como essas têm sido utilizadas como instrumento para a geoconservação e ações que propiciem a multiplicidade de usos que se esperam delas junto à população? 
No caso brasileiro, observa-se que cidades e grandes centros urbanos não conseguiram e não conseguem atender às necessidades de moradia, educação, saúde e bem-estar geral para os seus habitantes. A segregação social e espacial à qual parte da população é submetida se reflete em todos os patamares da vida urbana. Desta forma, buscou-se identificar as diferenças entre a distribuição e conservação das áreas verdes, abrangendo o maior número de Unidades Ambientais do Município, e levando em consideração sua localização em setores de alto padrão imobiliário e alta renda bem como naqueles de baixa renda e menor valorização dos imóveis. Desta forma, buscou-se também caracterizar como essas são tratadas pelo poder público, responsável por sua conservação e manutenção, e como a população as utilizam e as percebem.

Na tentativa de aferir o sentimento da população em relação aos espaços verdes públicos da cidade, indagou-se aos usuários sobre diversos aspectos de sua percepção acerca dessas áreas, abrangendo como a população vê a criação e manutenção de áreas verdes e parques urbanos e sua distribuição na cidade. A pesquisa buscou ainda estabelecer a assiduidade da frequência dos usuários, além de aspectos relativos à conservação, acessibilidade e qualidade da infraestrutura oferecida pelas áreas verdes.

Espaços verdes urbanos públicos são criados e gerenciados principalmente pelo poder público e tradicionalmente são os elementos mais valiosos das infraestruturas verdes urbanas. A cidade comporta e deve apresentar espaços verdes urbanos públicos de diferentes tipos em grau de naturalidade, cobertura vegetal, infraestruturas recreativas ou usos sociais que possam oferecer. É devido a essa diversidade na tipologia de seus espaços que advém a importância da compreensão das preferências dos moradores de uma cidade por uma determinada área, (MADUREIRA, 2018).

Apesar de ser compreendido pelas variadas normativas que regem o planejamento urbano que a população como um todo precisa de acesso à qualidade ambiental, e que este bem é fundamental para uma boa qualidade de vida, na prática a cidade continua negando esse recurso a grande parcela dos seus moradores. $\mathrm{O}$ uso frequente de parques e áreas verdes pode reduzir o stress e promover uma sensação de paz e tranquilidade, melhorar a saúde mental e psicológica e pode também incentivar o desenvolvimento de laços sociais aos frequentadores (LEE e KIM, 2015). As atitudes e comportamentos dos cidadãos em relação aos parques e áreas verdes citadinos são focos da atenção deste estudo.

A Organização Mundial de Saúde (WHOQOL-100,1995) define medidores para estimar a qualidade de vida que podem ser sobrepostos àqueles decorrentes da presença ou não de áreas verdes nos espaços urbanos. Verifica-se, que dentre diversos itens que aferem o bem-estar humano, vários podem ser correlacionados à presença e função precípua das áreas verdes; quais sejam: repouso, favorecimento às relações interpessoais, lazer, presença de ambiente físico saudável, conforto climático, práticas esportivas e recreação. 


\section{Área de Estudo e Unidades Ambientais}

A cidade do Recife, com $209 \mathrm{~km}^{2}$, é a capital do estado de Pernambuco e principal núcleo urbano da Região Metropolitana homônima, que perfaz a quinta maior aglomeração urbana do país. Localizada na costa oriental do Nordeste brasileiro, Recife tem um clima tropical úmido de costa oriental, com precipitações médias anuais próximas a $2.000 \mathrm{~mm}$, chuvas concentradas no outono-inverno, e temperatura média de $26^{\circ} \mathrm{C}$ (CORRÊA, 2006). A vegetação potencial da região, a floresta atlântica, foi substituída desde o início da colonização europeia, a partir de 1537, pela monocultura da cana de açúcar e, gradualmente, pelas formas urbanas de uso da terra. Situada ao redor do estuário comum dos rios Capibaribe e Beberibe, o sítio urbano da cidade é marcado por uma extensa planície, com baixios de maré e níveis de terraços marinhos e fluviais, cortados por diversos corpos d'água, alguns, como nas áreas centrais da cidade, ainda margeados por manguezais.

Tratando o sítio da cidade como um "geossistema" (CORREA, 2006) pode-se afirmar que o Recife tem características processuais comuns aos geossistemas urbanos, assim marcados pela erradicação da cobertura vegetal prístina, problemas de drenagem superficial, formação de ilhas de calor, escoamento de dejetos líquidos, abastecimento d'água e disposição dos resíduos sólidos. Todavia, devido à peculiaridade de sua estrutura geológico-geomorfológica, que alterna os terrenos de difícil drenagem da planície, com o semicírculo de colinas sedimentares de taludes instáveis que a envolve, o relevo foi escolhido como elemento norteador da subdivisão desse geossistema em unidades ambientais. Estas, apesar de coincidirem bastante com a compartimentação geomorfológica do município, apresentam características processuais próprias.

Utilizou-se a compartimentação do município do Recife em unidades ambientais (CORREA, 2006, p. 86102) e geomorfológicas (SOUZA, CORRÊA e SILVA, 2017, p. 147-168) para fins de localização do suporte físico paisagístico das áreas verdes da cidade do Recife e identificação daquelas sobre as quais voltou-se o foco da pesquisa (Figura 01). As unidades ambientais identificadas e objeto deste trabalho são: 1.Terraço Marinho Holocênico, 2. Colinas, 3.Terraço Marinho Pleistocênico, 4.Terraço Flúvio marinho Holocênico , 5.Planície de Restinga, 6.Planície de Maré, 7.Planície Flúvio lagunar, 8.Planície Colúvio-aluvial indiferenciada, 9.Terraço Indiferenciado e 10.Corpos Hídricos e Canais Fluviais.

A localização das áreas verdes foi realizada através do banco de dados da Prefeitura da Cidade do Recife, a partir do qual as mesmas foram inseridas no mapa geral das unidades ambientais mapeadas (figura 1). As áreas de estudo foram mapeadas individualmente para as unidades ambientais mediante o uso do software ARCGIS. 
Figura 1. Unidades Ambientais da Cidade do Recife e áreas verdes públicas estudadas. Fonte: Os autores.

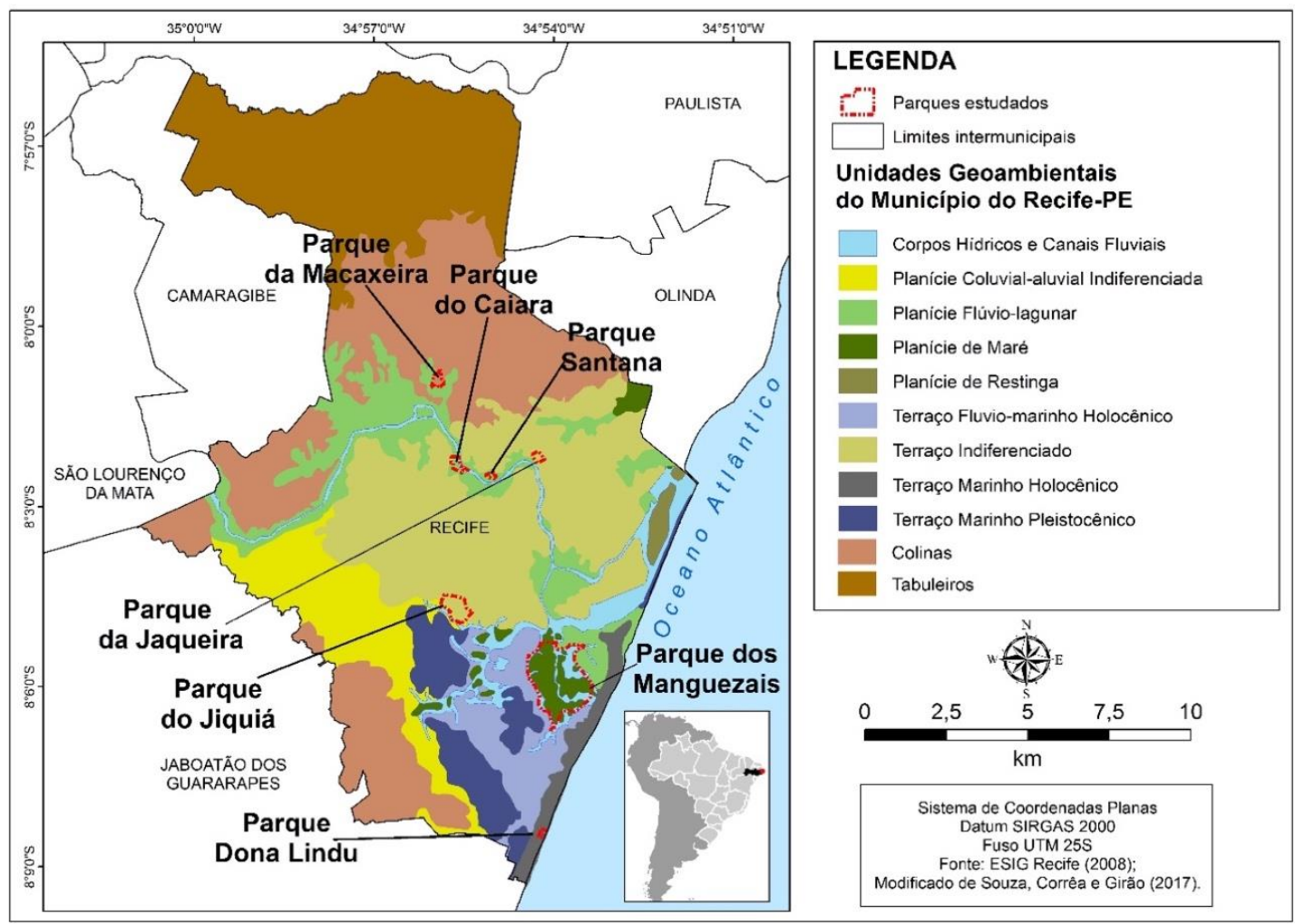

\section{MATERIAIS E MÉTODOS}

Para alcançar o objetivo desta pesquisa, foi elaborado um mapeamento das unidades ambientais, bem como mapeamento das áreas verdes existentes, além de visita de campo em situações específicas de necessidade de atualizar as bases cartográficas e tipologias de uso.

A elaboração dos produtos cartográficos seguiu dois procedimentos básicos: aquisição das bases e processamento das mesmas para a confecção dos mapas. Com relação ao mapa de unidades geoambientais do município do Recife, fez uso dos trabalhos de Fonseca, Corrêa e SILVA (2016, p. 201-219).

e Souza, Corrêa e Silva (2017, p. 147-168). A partir destas bases preexistentes, montou-se um mosaico de unidades de paisagem para a área de estudo. As bases foram exportadas, georreferenciadas e vetorizadas em ambiente SIG, software ArcGIS 10.3. Trabalhou-se com o datum Sirgas 2000, no sistema de coordenadas geográficas.

Os limites das áreas verdes estudadas foram obtidos junto ao Portal Esig (2008), base de dados geoespaciais do Recife, equivalendo às malhas oficiais estabelecidas pelo plano diretor do referido município. Esses dados foram plotados no mapa de unidades geoambientais, onde se procedeu com a análise geossistêmica dos recortes alvos deste estudo. 
Cartas de paisagem gerais foram elaboradas para cada uma das áreas verdes estudadas. Nestas, enfocou-se as unidades geoambientais nas quais os parques e seus entornos se inserem, destacando-se as zonas de transição sempre que presentes. Destaca-se ainda que as Unidades Ambientais (CORRÊA, 2006) configuram recortes sintéticos da paisagem física do município, estabelecidas inicialmente sobre os compartimentos geomorfológicos e tipologias lito-estratigráficas subjacentes. No entanto, essas unidades são acrescidas de seu comportamento processual e potenciais riscos, o que lhes confere um desejável aspecto sistêmico e integrador, bem ajustado aos propósitos deste trabalho.

Os aspectos sociais relacionados às áreas verdes estudadas foram aferidos diretamente com base na aplicação e análise de formulários, semiestruturados, voltados para segmentos diversos dos usuários e potenciais usuários das áreas foco desta pesquisa. Esse levantamento constituiu a etapa de campo da pesquisa.

Esta etapa da investigação esteve voltada para o entendimento das necessidades e anseios da população no que diz respeito às áreas verdes, seja como espaços de convivência, áreas de conservação da geodiversidade, parques e praças voltados ao lazer e à recreação, etc. As perguntas foram fechadas, claras e objetivas para obtenção de respostas curtas e previsíveis. Desta forma, foram elaboradas perguntas diretas, para as quais respostas de 0 a 10 marcam o nível de satisfação, onde 0 é igual a "muito pouco" e 10 equivale a "bastante" (COSTA et al., 2008).

\section{RESULTADOS E DISCUSSÕES}

A produção de um inventário tratando da distribuição das unidades ambientais da cidade do Recife e as áreas verdes estudadas neste trabalho, evidenciou uma ocorrência dessas últimas dispersas pelo território do município, que no caso do Recife por ser quase 100\% urbano, confunde-se com a própria cidade. Não obstante, as áreas verdes não abrangem todas as regiões de grande concentração populacional e, portanto, não atendem toda a demanda dos cidadãos pelas amenidades e melhoria da qualidade de vida propiciadas pela presença dessas estruturas. Verificou-se a ocorrência de áreas verdes públicas sob a forma de parques em 5 unidades ambientais e 8 bairros na cidade do Recife (Quadro 1):

Quadro 1. Distribuição das áreas verdes públicas do Recife por unidade ambiental e bairro

\begin{tabular}{|l|l|l|}
\hline Unidade Ambiental & Bairro & Área \\
\hline Terraço Marinho Holocênico & Boa Viagem & Parque Esplanada Dona Lindu \\
\hline Colinas & Macaxeira & Parque Macaxeira \\
\hline Terraço Marinho Pleistocênico & Jiquiá & Parque do Jiquiá \\
\hline \multirow{2}{*}{ Planície de Maré } & Pina/Boa Viagem & Parque dos Manguezais \\
\cline { 2 - 3 } & Pina & Parque do Encanta Moça (projeto) \\
\hline \multirow{3}{*}{ Planície Flúvio-lagunar } & Jaqueira & Parque da Jaqueira \\
\cline { 2 - 3 } & Iputinga & Parque do Caiara (abandonado) \\
\cline { 2 - 3 } & Santana & Parque de Santana \\
\hline
\end{tabular}


Verificou-se que nas 5 unidades ambientais-geomorfológicas restantes que integram o município do Recife não foram identificadas áreas verdes públicas de expressão espacial significativa além de praças, canteiros e arborização viária. Ressalta-se que essas abrangem a grande maioria dos bairros num total de 40 (Quadro 2).

Quadro 2. Unidade ambientais e bairros desprovidos de áreas verdes públicas.

\begin{tabular}{|c|c|}
\hline Unidade Ambiental & Bairro \\
\hline \multirow{6}{*}{ Terraço Flúvio-marinho Holocênico } & Areias \\
\hline & Caçote \\
\hline & Estância \\
\hline & Ibura \\
\hline & Imbiribeira \\
\hline & Ipsep \\
\hline Planície de Restinga & Brasília Teimosa \\
\hline \multirow{8}{*}{ Planície colúvio-aluvial indiferenciada } & Barro \\
\hline & Coqueiral \\
\hline & Curado \\
\hline & Jardim São Paulo \\
\hline & Jordão \\
\hline & Sancho \\
\hline & Tejipió, \\
\hline & Várzea \\
\hline \multirow{3}{*}{ Terraço Indiferenciado } & Centro da Cidade (06 bairros) \\
\hline & Zona Norte (18 bairros) \\
\hline & Zona Oeste (19 bairros) \\
\hline
\end{tabular}

Foi construída uma síntese das informações ambientais e sua relação com a distribuição das áreas verdes públicas no município do Recife, levando em consideração seus aspectos morfológicos, processos superficiais e o estado de conservação das áreas verdes (Quadro 03). Por fim apresenta-se uma descrição das principais áreas verdes estudas nas quais foram conduzidos questionários com os usuários. 
Quadro 3. Unidades Ambientais da Cidade do Recife, suas morfologias, seus processos de superfície, as ocorrências de áreas verdes e o estado de conservação

UNIDADES AMBENTAIS DA CIDADE DO RECIFE, MORFOLOGIAS/PROCESSOS DE SUPERFÍCIE/OCORRÊNCIAS DE AV e ESTADOS DE CONSERVAÇÃO

\begin{tabular}{|c|c|c|c|c|c|c|c|c|}
\hline & UNIDADE AMBIENTAL & BAIRRO & MORFOLOGIA & PROCESSOS DE SUPERFFICIES & AREA VERDE / PARQUE & $\overline{\text { AREA }}$ & TIPO DE USO & ESTAdO dE CONSERVAÇ̄̃o \\
\hline & $\begin{array}{l}\text { TERRAÇO MARINHO } \\
\text { HOLOCÉNICO }\end{array}$ & Boa Viagem, Pina, & $\begin{array}{l}\text { Cordd̄es litorâneos alongados, paralelos à } \\
\text { linha de costa }\end{array}$ & $\begin{array}{l}\text { Acăo das marés, ondas, correntes, } \\
\text { erosão marinha decorrente de } \\
\text { construcōoes irregulares. }\end{array}$ & DONA LINDU & $27.000 \mathrm{~m} 2$ & $\begin{array}{l}\text { Parque Esplanada, } \\
\text { teatro, auditório, } \\
\text { lazer. }\end{array}$ & $\begin{array}{l}\text { EXCELENTE. } \\
\text { Frequencia de utilização por }\end{array}$ \\
\hline & CounAs & Macaxeira & 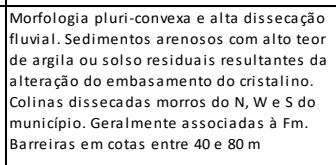 & $\begin{array}{l}\text { Aç̃̃o antrópica, desmatamento } \\
\text { para moradia e arricultura. } \\
\text { Reirada de cobertura vegetal } \\
\text { original. }\end{array}$ & \begin{tabular}{|l|} 
JARDIM BOTÂNICO, MACAXEIRA, \\
SíTIO DA TRINDADE, DOIS IRMÄOS
\end{tabular} & $100.000 \mathrm{M} 2$ & $\begin{array}{l}\text { Parque comunitátio, } \\
\text { academia da cidade, } \\
\text { pistas de caminhada } \\
\text { e corrida, lazer }\end{array}$ & $\begin{array}{l}\text { BOM. } \\
\text { Frequencia de utilização por } \\
\text { parte dos cidadãos: ALTA }\end{array}$ \\
\hline & $\begin{array}{l}\text { TeRRAÇO MARINHO } \\
\text { PLEISTOCENICO }\end{array}$ & 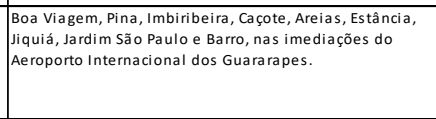 & Cordōes arenosos no interior da superfície & $\begin{array}{l}\text { Escoamento superficial fora do } \\
\text { alcance das marés, } \\
\text { impermeabilização do solo e } \\
\text { geraçăo de alagamentos }\end{array}$ & JIQUUÁ & $32.400 \mathrm{M} 2$ & 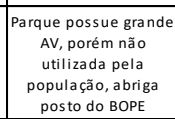 & $\begin{array}{l}\text { PésSIMO. } \\
\text { Frequencia de utilizacăão por } \\
\text { parte dos cidadãos:BAIXA. }\end{array}$ \\
\hline & $\begin{array}{l}\text { TERRACO FLÚVIOMARINHO } \\
\text { HOLOCENICO }\end{array}$ & $\begin{array}{l}\text { Boa Viagem, Imbiribe ira, Ipsep, Ibura, Caçote, Areias, } \\
\text { Estância e Jiquiá }\end{array}$ & $\begin{array}{l}\text { Faixa areno-argilosa encaixado entre os } \\
\text { Terra cos Marinhos Holocénico e } \\
\text { Pleistocénico }\end{array}$ & $\begin{array}{l}\text { Escoamento superficial difuso e } \\
\text { Intenso retrabal hamento fluvial, } \\
\text { ocorrência de enchentes e } \\
\text { alagamentos. }\end{array}$ & SEM REPRESENTAÇ̃̃o & & & \\
\hline & PLANÍCII DE RESTINGA & Pina e Brasilia Teimosa & $\begin{array}{l}\text { Cordão arenoso no contato como oceano e } \\
\text { modelado por process so flluviai is. }\end{array}$ & 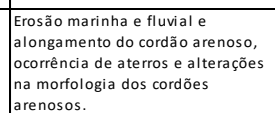 & SEM REPREEENTAÇ̃̃o & & & \\
\hline & PLANÍCIE DE MARÉ & 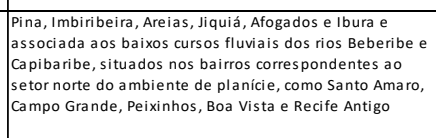 & $\begin{array}{l}\text { Areas planas situadas ao longo dos baixos } \\
\text { cursos fluviais sob a forma de manguezais }\end{array}$ & 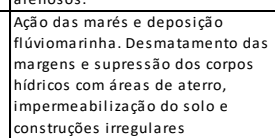 & $\begin{array}{l}\text { PARQuE DOS MANGUEZAIS, ENCANTA } \\
\text { MOCGA(BUFER ZONE) }\end{array}$ & $\begin{array}{l}320.340 \mathrm{~m} 2 / \\
182.000 \mathrm{~m} 2\end{array}$ & $\begin{array}{c}\text { Parque Conservaçăo- } \\
\text { Propriedade da } \\
\text { Marinha }\end{array}$ & $\begin{array}{l}\text { EXCELENTE. } \\
\text { Frequencia de utilizacãoo por } \\
\text { parte dos cidadãos: ZERO- AREA } \\
\text { DE MARINHA }\end{array}$ \\
\hline & PLANícIe FLÚVIolagunar & 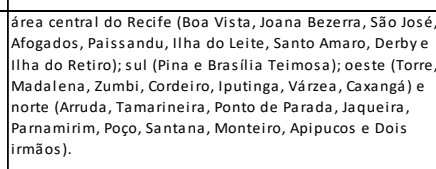 & $\begin{array}{l}\text { Áreas planas margeando os curros fluviais } \\
\text { até o interior da planíice. }\end{array}$ & $\begin{array}{l}\text { Erosão e deposiçẵo nas margens } \\
\text { dos rios, ocupaçăo por áreas } \\
\text { residenciais e agricolas. }\end{array}$ & $\begin{array}{l}\text { PARQUE JAQUEIRA, SANTANA, } \\
\text { CAIARA, APIPUCOS, }\end{array}$ & $\begin{array}{l}70.000 \\
\mathrm{M} 2 / 63.00 \mathrm{M} 2 / \\
18.000 \mathrm{M} 2\end{array}$ & $\begin{array}{l}\text { Parques comunitários, } \\
\text { pistas de caminhada } \\
\text { e corrida, lazer. }\end{array}$ & $\begin{array}{l}\text { EXCELENTE/EXCELENTE/PÉSSIMO } \\
\text { respectivamente } \\
\text { |Frequencia de utilização por } \\
\text { parte dos cidadãos: } \\
\text { ALTA/MÉDIA/BAIXA - } \\
\text { respectivamente }\end{array}$ \\
\hline & \begin{tabular}{|l} 
PLANICIE COLÚVIO-ALUVIAL \\
INDIFERENCIADA
\end{tabular} & 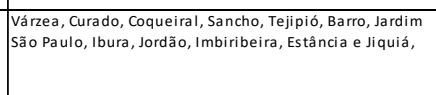 & $\begin{array}{l}\text { Áreas planas a levemente inclinadas no } \\
\text { contato com as colinas da formação } \\
\text { barreiras }\end{array}$ & $\begin{array}{l}\text { Erosão no alto curso e deposiçăo } \\
\text { no baixo curso dos rios, } \\
\text { movimentos de massa nas áreas } \\
\text { com maior declividad }\end{array}$ & SEM REPRESENTAC̄̃̃o & & & \\
\hline & TERRAÇO INDIFERENCIADO & 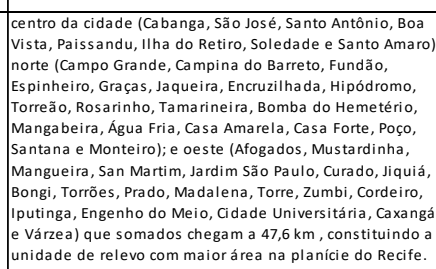 & $\begin{array}{l}\text { Grande variação morfológica ao longo dos } \\
\text { setores da planicie. }\end{array}$ & $\begin{array}{l}\text { Escoamento difuso fora do alcance } \\
\text { da marés, urbanizizacáo intensad, } \\
\text { aterros, impermeabilizaçao dos } \\
\text { solos e g geraçăo de alagamentos. }\end{array}$ & PARQQUE 13 DE MAIO & & & \\
\hline & $\begin{array}{l}\text { CORPOS HÍDRICOS E CANAIS } \\
\text { FLUVIAAIS }\end{array}$ & & 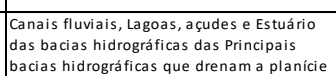 & $\begin{array}{l}\text { Escoamento de água e sedimentos } \\
\text { a partir de fluxos canalizados. } \\
\text { canalizaça, retificaçăo }\end{array}$ & LAGOA DO ARAÇA & & & \\
\hline
\end{tabular}


Terraço Marinho Holocênico/Parque Dona Lindu: Segundo apontam Souza, Corrêa e Silva (2017, p. 147-168), o Terraço marinho holocênico é composto pelos sedimentos quartizarênicos formados a partir da transgressão marinha ocorrida há cerca de 5.100 anos A.P. Esta unidade está situada na porção litorânea da planície sob a forma de cordões litorâneos alongados, contínuos e paralelos ao oceano.

Com uma área de 4 km², largura média de $1 \mathrm{~km}$ e altitudes entre 2 a $4 \mathrm{~m}$, são representados pela atual linha de costa, que se estende entre os bairros de Boa Viagem e Pina, na zona sul do Recife. É perceptível a ocorrência de erosão do prisma praial como resultado do avanço da urbanização em direção ao litoral, gerando recuo da linha de costa. Inserido nesta unidade, na zona sul de alto valor imobiliário está o Parque Dona Lindu com 2,7 ha de área (figura 2), que embora tenha resultado de uma demanda da comunidade por uma área verde no bairro, caracteriza-se por ser um parque esplanada, projetado pelo arquiteto Oscar Niemeyer, com teatro, galeria de arte e amplas áreas pavimentadas.

Figura 2. Aspecto geral e mapa de unidades ambientais do Parque Dona Lindu. Fonte: Os autores

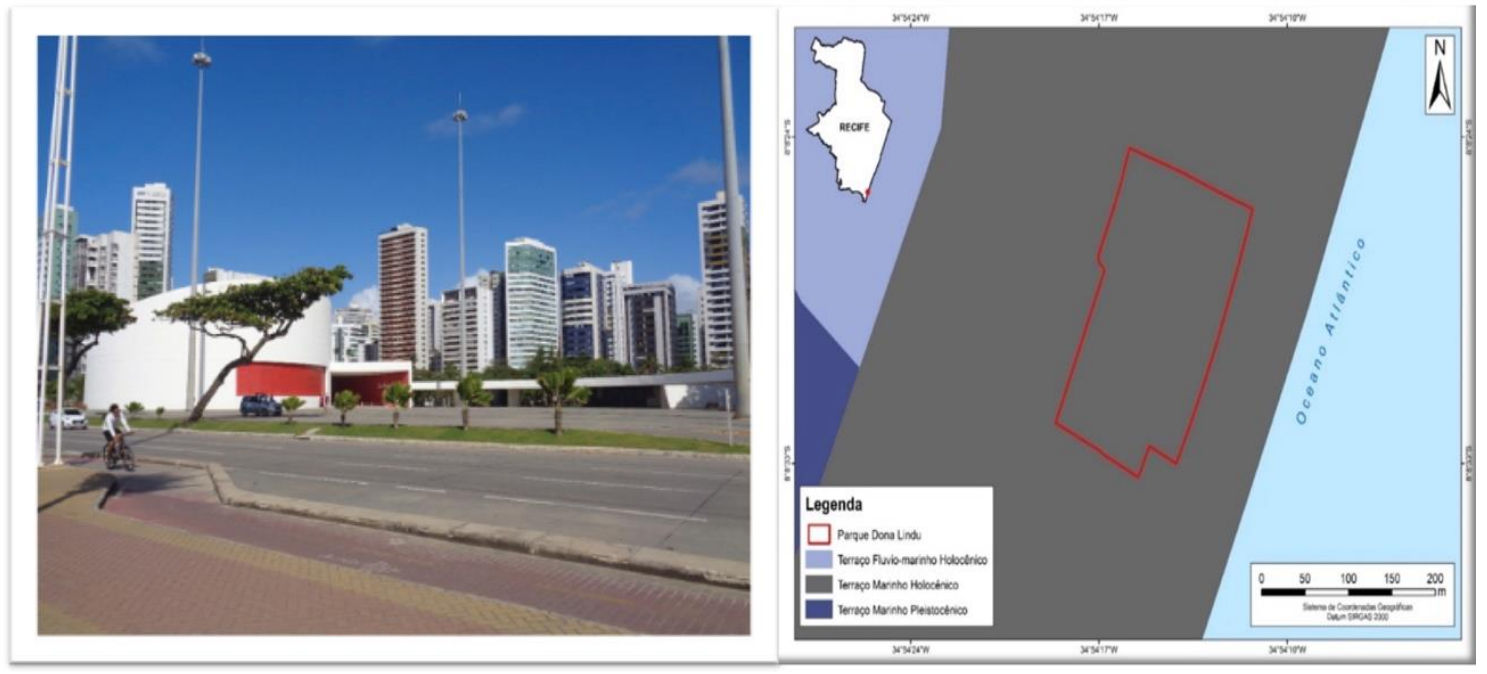

Colinas/Parque da Macaxeira: A unidade Colinas (figura 03) identificada por Corrêa (2006, p. 86-102), apresenta relevo de colinas dissecadas situados a N, W e S do município do Recife, geralmente associado à Fm. Barreiras, composta localmente por sedimentos inconsolidados areno-argilosos, em cotas entre 40 e 80 m. Sua morfologia é pluri-convexa e apresenta alta dissecação fluvial. Essa unidade é acometida por movimentos de massa nas encostas, sobretudo deslizamentos translacionais rasos, que afetam as comunidades ali instaladas.

Sobre a unidade Colina localiza-se o único parque metropolitano em área de encosta da cidade do Recife. Inaugurado em 2014, o parque da Macaxeira foi estabelecido em uma antiga fábrica de tecidos, tendo 
sido a área repaginada para dar lugar a uma escola municipal e ao referido parque. Com uma área é de 10 ha, o parque é bastante frequentado nos finais de semana pela população de seu entorno, principalmente moradores do bairro da Macaxeira. Durante os dias de semana, há uso das instalações da Academia da Cidade nos horários entre 6 as 9:30 hs, ocorrendo também grande uso da pista de caminhada e corrida. Após esse horário, nota-se o relativo esvaziamento do parque, o que pode decorrer da falta de áreas arborizadas, o que torna o calor mais intenso, até o pôr do sol.

Figura 3. Aspecto geral e mapa de unidades ambientais do Parque da Macaxeira. Fonte: Os autores

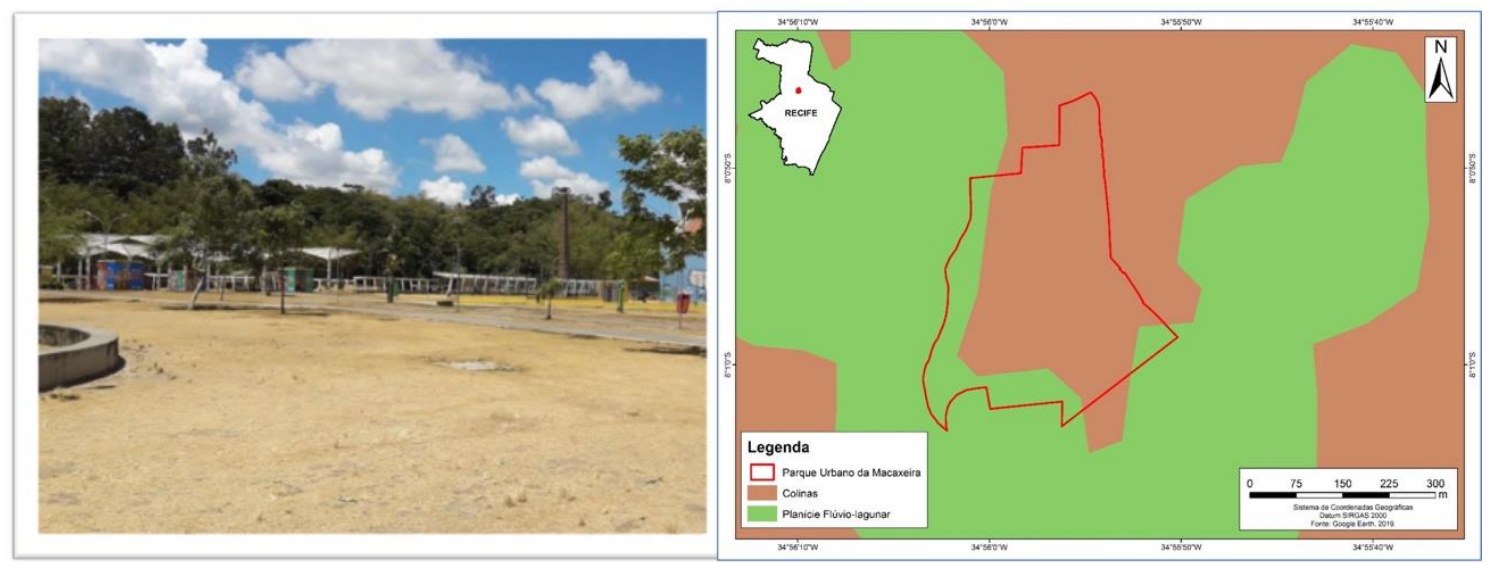

Terraço Marinho Pleistocênico/Parque do Jiquiá: Este parque situa-se sobre a unidade do Terraço Marinho Pleistocênico segundo Souza, Corrêa e Silva (2017, p. 147-168), constituído pelos sedimentos depositados pela penúltima transgressão marinha há cerca de 120.000 anos A.P, localizados na porção mais interna da planície flúvio-marinha do Recife sob a forma de antigas cristas praiais com cotas altimétricas variando entre 6 e $12 \mathrm{~m}$ e uma área de pouco mais de $10 \mathrm{~km}^{2}$. Sobre esta unidade os resultados das transformações antrópicas são percebidos por meio da impermeabilização do solo com concreto, asfalto e pavimento, impedindo a infiltração de água e favorecendo o escoamento superficial, gerando alagamentos em dias chuvosos.

A área verde pública representada nesta unidade ambiental é o Parque do Jiquiá ocupando 32,4 ha (figura 4) na zona oeste da cidade do Recife. O parque hoje abriga um posto de policiamento do BOPE (Batalhão de Operações de Polícia), e não é utilizado pela população, nem mesmo pelos moradores do entorno. Sua manutenção é negligenciada e não há programações de eventos por parte de órgãos responsáveis - Prefeitura Municipal ou Governo do Estado.

Há projeto sem perspectiva de execução para sua recuperação e restauração desde 2012 (Jornal do Comercio, 2012), haja visto que o parque possui a única torre de atracação do dirigível Zepellin restante no 
mundo, além de paióis da segunda guerra mundial (Jornal do Comercio, 2017). Ainda segundo a mesma matéria jornalística, o sentimento da população do entorno à época era de que o Parque é uma grande área que poderia ser utilizada para o bem-estar de todos.

Figura 4. Aspecto geral e mapa de unidades ambientais do Parque do Jiquiá. Fonte: Os autores
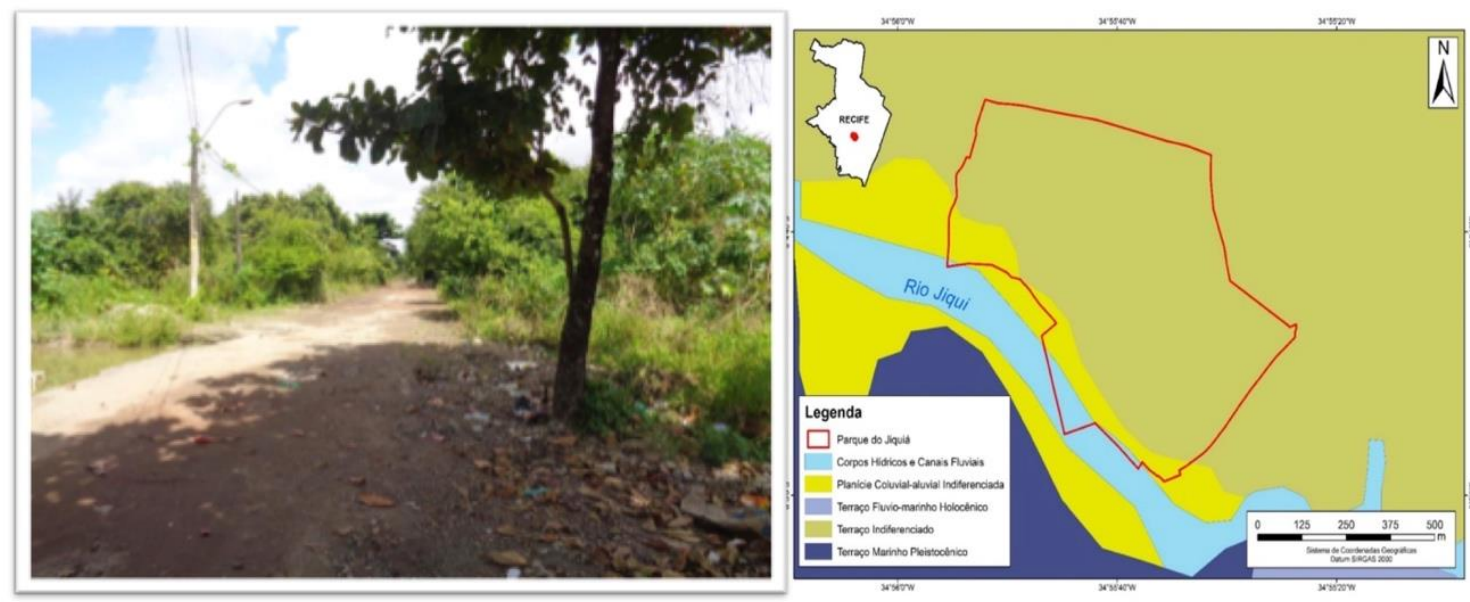

Planície de Maré/Parque dos Manguezais e Parque Encanta Moça: A unidade de Planície de maré definida por Souza, Corrêa e Silva (2017, p. 147-168), compreende regiões planas situadas na zona de contato entre os baixos cursos fluviais das áreas que sofrem influência da maré que compõem os manguezais (Figura 5), e que se adaptam a um substrato formado pelos sedimentos argilosos de mangue e à variação de volume e salinidade da água. Com uma área de $5 \mathrm{~km}^{2}$, a planície de maré localiza-se no estuário comum compreendido pelas bacias dos rios Pina, Beberibe e Capibaribe. Sobre a unidade é verificada a ação de marés, erosão e sedimentação fluvial. Apresenta episódios de enchentes decorrentes do desmatamento no entorno dos corpos hídricos, aterros, impermeabilização do solo e construções irregulares.

Criado em 1996 pela Lei de Uso do Solo e posteriormente regulamentado em 2010, o Parque dos Manguezais foi transformado em unidade ambiental protegida pelo decreto $\mathrm{n} 025.565$ de 01 de dezembro de 2010 que "Regulamenta a unidade protegida Parque dos Manguezais/Parque Josué de Castro, em conformidade com o Plano Diretor do Recife - Lei Municipal no 17.511/2008 e com a Lei Federal no 9.985/2000 que institui o Sistema Nacional de Unidades de Conservação da Natureza - SNUC" (leismunicipais.com.br). Com uma área de 320,34 ha foi transformada em unidade de Conservação da Natureza, na categoria de parque natural municipal, estando este no grupo de proteção integral, de acordo com a lei federal no 9.985/2000. (Brasil, 2001)

Sendo a maior área de mangue em zona urbana no Brasil, o Parque dos Manguezais, tem um papel importante, não só ambiental, mas também social, já que pescadores e marisqueiros vivem em comunidades 
e vilas, em suas palafitas às margens dos rios e canais de maré. Não obstante, a poluição e o odor decorrentes do lançamento de esgotos e lixo não tratado, contribuem para a degradação contínua dessa unidade de conservação, apesar das ações de conscientização ambiental tais como as promovidas pela Secretaria de Meio ambiente da cidade do Recife.

Vizinho ao Parque dos Manguezais está o terreno já designado pela PCR para a construção de habitações populares, o qual trataremos como Parque do Encanta Moça em área do antigo aeroclube da cidade. Neste sítio em 15 de março 1940 foi inaugurado o aeroclube de Pernambuco, que servia para pousos e decolagens de aviões de pequeno porte, além de aulas de pilotagem. As atividades do aeroclube foram encerradas devido à desapropriação do terreno para construção da via Mangue em 2013, que hoje margeia o Parque dos Manguezais, separando-o em boa parte do seu percurso das construções residenciais do bairro de Boa Viagem. Ressalta-se ainda a presença de um grande empreendimento comercial nesta área, o Shopping RioMar, de alto padrão, ao qual se somam 2 torres empresariais que trouxeram alto fluxo de automóveis e pessoas para esta área.

A área do Encanta Moça, hoje sem uso, é alvo de uma discussão entre a sociedade e poder público. Para este último seu destino deveria ser a construção residencial, enquanto a população em geral clama por um parque público que atenderia aos anseios dos moradores das áreas circunvizinhas. De acordo com resultados aferidos dos questionários aplicados, constata-se o anseio da população por novas áreas verdes públicas. A análise ora realizada permite aventar que em um futuro próximo o terreno do Encanta Moça possa dar lugar a um parque nos moldes de uma "buffer zone" ou zona de amortecimento da zona de preservação natural à qual se justapõe: O Parque dos Manguezais. Os parques em zonas de amortecimento atuam para atender a população do entorno e a população em geral de uma cidade, com fins mistos ecológico e recreacional, cujo intuito segundo Arnberger et al (2013), em estudos realizados em Viena, Áustria, é a redução em até 30\% da quantidade de pessoas que ingressam na área de preservação estrita à qual essa se justapõe.

Figura 5. Aspecto geral e mapa de unidades ambientais do Parque dos Manguezais. Fonte: Os autores
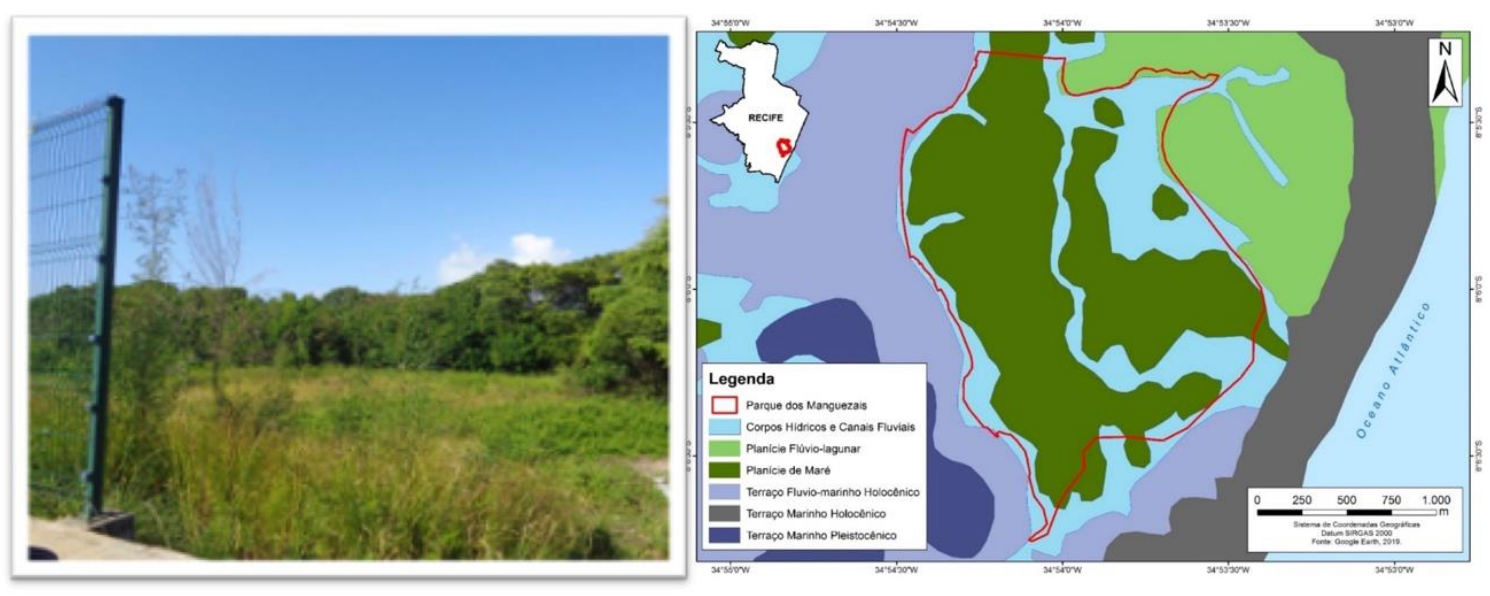
Planície Flúviolagunar/Parque da Jaqueira, Parque Santana e Parque do Caiara: A Planície flúviolagunar (SOUZA, CORRÊA e SILVA, 2017, p. 147-168) compreende áreas baixas sujeitas a inundações periódicas, compostas pelos sedimentos flúvio-lagunares, resultantes da deposição fluvial. Localiza-se nas proximidades dos cursos dos rios Capibaribe e Beberibe, se estendendo como uma franja ao longo dos mesmos em direção ao interior da planície. Ocupa uma área de $23,4 \mathrm{~km}^{2}$ onde há um predomínio dos processos de erosão e acumulação de sedimentos nas áreas adjacentes ao canal fluvial.

Observa-se, no Recife, o Parque da Jaqueira que conta com a presença de população flutuante em virtude da concentração de escolas, comércio etc. (figura 6). Iniciativas municipais como academia do bairro, aulas de yoga, e ginástica ao ar livre com orientadores, trazem a população para uma convivência social e prática esportiva. Este parque conta também com a Capela de Nossa Senhora da Conceição das Barreiras, aberta a casamentos e batizados, o que torna a área ainda mais movimentada e atrativa, além das missas celebradas aos domingos pela manhã. Está situado entre comércio variado de alto padrão, galerias de lojas, livrarias e cafés, além de escolas e colégios particulares de médio e grande porte.

Figura 6. Aspecto geral e mapa de unidades ambientais do Parque da Jaqueira. Fonte: Os autores

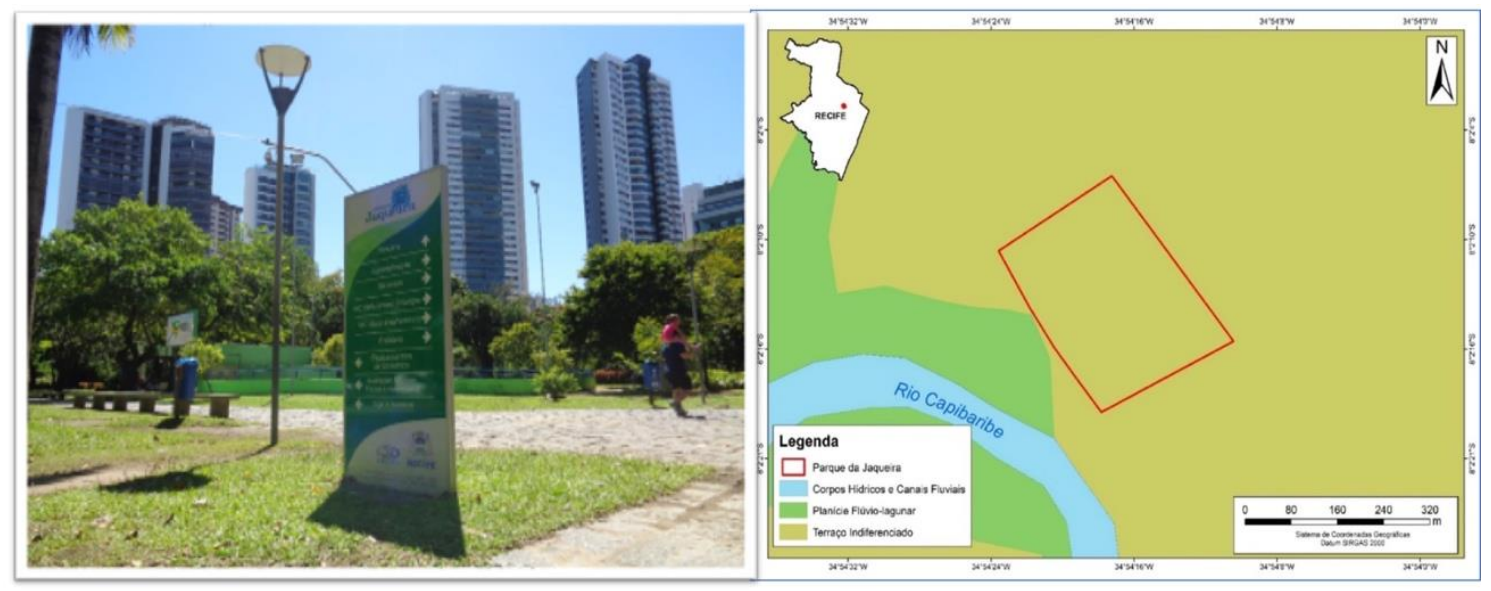

Por sua vez, o Parque Santana, inaugurado em 1958, contava inicialmente com 2,6 ha, hoje, após reformas e expansão, conta com 6,3 ha, dos quais $40 \%$ são de área verde (figura 7). Eventos como festival de jazz e shows são realizados frequentemente e suas árvores de grande porte à beira do rio Capibaribe constituem em um atrativo a mais para apreciação da natureza para os frequentadores. Como equipamentos, este parque possui academia da cidade, campo de futebol, quadra de tênis, pistas de skate, bicicross, caminhada, corrida e de bicicleta, além de atrações como "Parcão", espaço exclusivo para cachorros. Sua frequência durante a semana é baixa, uma vez que linhas de ônibus nessa região são escassas, ficando seu acesso limitado às pessoas que moram no entorno. 
Registramos ainda que o Parque Santana não possui comércio fixo nas suas imediações, predominando residências e o comércio informal nos finais de semana para atender os frequentadores. Dentre os atrativos destacam-se a academia da cidade, aulas de yoga, pista para caminhada e corrida e áreas específicas para grupos de ginástica funcional e ciclismo. O parque é também muito utilizado para aulas de fotografia, e elaboração de books fotográficos, uma vez que suas flores e canteiros estão sempre bem cuidados.

Figura 7. Mapa Parque Santana. Fonte: Os autores
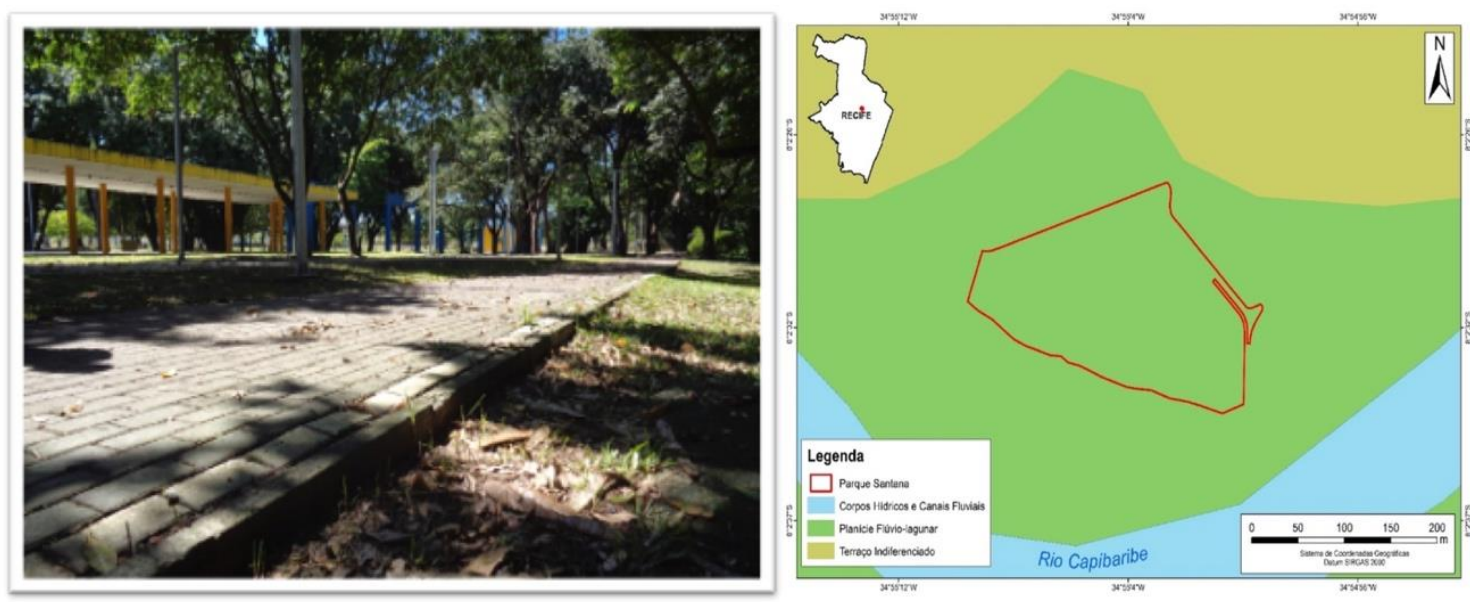

Parque do Caiara (figura 08), com 18 ha de área, apresenta uma estrutura de quadras poliesportivas, pista de caminhada, corrida, skate, além de um píer em madeira às margens do rio Capibaribe. O Parque encontra-se correntemente abandonado, não sendo nem mesmo utilizado pela população do entorno, que concentra comunidades baixa renda. Não apresenta arborização e a insolação durante a maior parte do dia se faz bastante intensa. Constatou-se que a manutenção é infrequente, e na área vegetada por gramíneas e arbustos observou-se a presença de animais pastando, sendo essa a maior utilidade aparente da área para a população circunvizinha. A absoluta ausência de frequentadores durante as visitas de campo ao parque fato inviabilizou a aplicação de questionários.

Figura 8. Mapa Parque do Caiara. Fonte: Os autores 


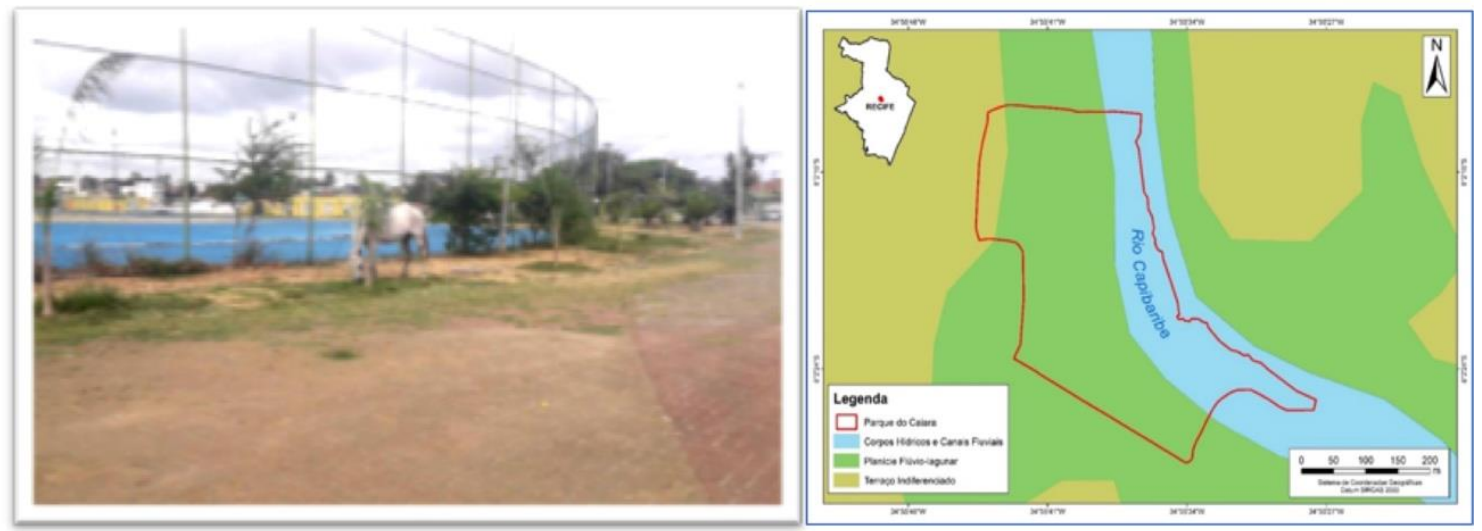

\section{Aplicação e análise dos Questionários}

Um segundo resultado foi obtido na pesquisa por meio da aplicação de um questionário aos usuários das áreas verdes em estudo, buscando evidenciar qual a percepção destes em relação a tais áreas na cidade do Recife como um todo e especificamente para a área em que se encontravam. A aplicação do formulário buscou identificar qual o sentimento e a consciência do cidadão para com a utilização do parque e/ou área verde específica da entrevista realizada, como esta influência em seu cotidiano, e qual sua percepção do de como o poder público tem gerenciado essas áreas.

As respostas aos questionários retratam o sentimento da população do entorno das áreas verdes, não só de usuários especificamente, mas também de moradores e trabalhadores que se utilizam dos equipamentos de comércio dos arredores dessas áreas. Mostra-se evidente o anseio por um espaço de convívio para famílias e para a população em geral, principalmente em áreas degradadas e com falta de manutenção e segurança, onde o sentimento geral dos entrevistados é de que parques e área verdes com usos, como academia da cidade, pistas de caminhada, corrida, prática de skate entre outros, e boa manutenção por parte do poder público, traria comércio e segurança para o entorno, além de valorizar os imóveis dos arredores.

Primeiramente foi requisitado aos usuários dos espaços verdes públicos visitados, que atribuíssem uma nota de 0 a 10, sendo 0 equivalente ao conceito "muito pouco" e 10 "demais", a determinados aspectos locacionais gerais das áreas verdes da cidade. Em primeiro lugar, as pessoas foram indagadas acerca da quantidade de áreas verdes públicas disponíveis no Recife, localização das áreas em relação à zona central da cidade (centralidade) e concentração em determinadas áreas da cidade. Para cada questão foram entrevistados 100 usuários sendo os resultados por nota atribuída a cada item plotados em porcentagem. 
Em relação à quantidade de áreas verdes verificou-se que a maioria dos entrevistados, 41,2\%, consideraram o número de áreas adequado (nota 5), apenas 3\% consideram que há um excesso de espaços verdes (nota 10 ) ao passo que $6 \%$ acham que há poucas áreas verdes na cidade (nota 0 ). Já quanto à distribuição há uma dispersão maior de notas, com $42 \%$ dos entrevistados considerando o padrão com tendência à concentração espacial em certos bairros (notas 7 e 8), sendo que $6 \%$ consideram que essa concentração é excessiva (nota 10). Em relação à centralidade, as respostas indicam um padrão quase diametralmente oposto ao do item anterior, com $42 \%$ dos entrevistados considerando que as áreas verdes se situam em bairros razoavelmente mais afastados do centro (notas 2, 3 e 4), sendo que 13\%, a quarta maior classe modal, acredita que as áreas verdes estão mais representadas nos bairros centrais da cidade (Figura 09).

Figura 9. Distribuição percentual das respostas pelas notas de 0 a 10 relativas à distribuição, centralidade e quantidade de áreas verdes públicas na cidade do Recife. Fonte: Os autores

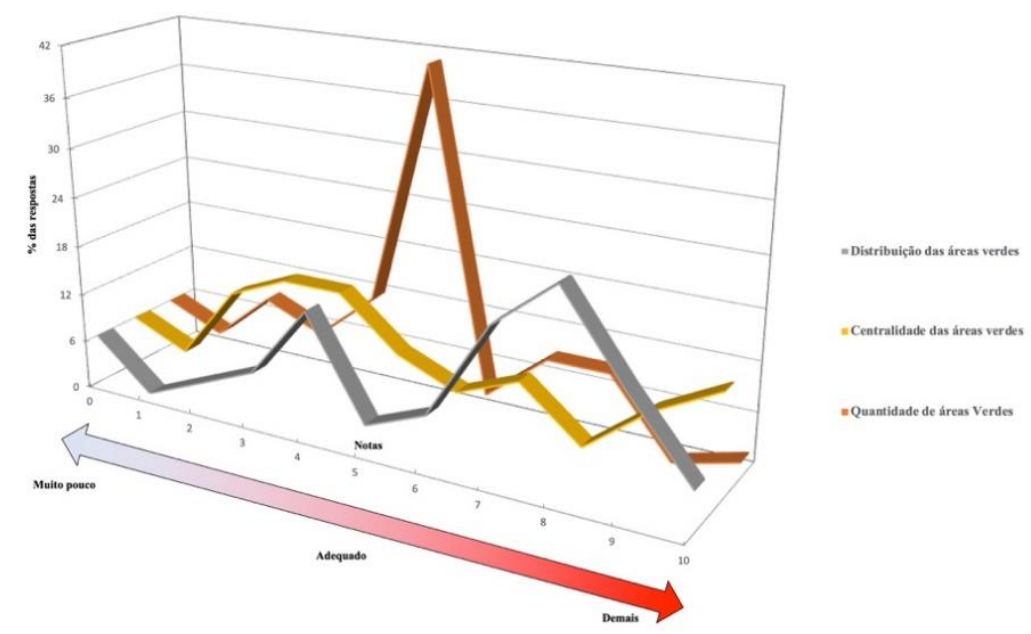

Outra questão que integra a parte geral do questionário, aborda a necessidade ou não de criar novos espaços verdes públicos na cidade, a localização ideal, as atividades econômicas no entorno das áreas verdes e a influência das áreas verdes públicas sobre o valor dos imóveis no entorno. Os efeitos benéficos da implementação dessas áreas predominaram na maioria das respostas, com atribuição da nota 10, em todos os itens variando de 58 a $94 \%$ das repostas.

O mesmo ocorre em relação ao mercado imobiliário, o qual 73\% dos entrevistados acreditam que as áreas com implantação de novos espaços verdes apreciarão um aumento efetivo do valor dos imóveis situados em suas imediações, o que em última análise pode não ser benéfico para as áreas de baixa renda, uma vez que o aumento do valor dos imóveis poderá resultar em gentrificação da área e expulsão dos moradores originais (tabela 01). 
Tabela 1. Opinião dos entrevistados em relação à implantação de novas áreas verdes na cidade do Recife (dados em \%)

\begin{tabular}{|c|c|c|c|c|c|c|c|c|c|c|c|c|}
\hline \multicolumn{8}{|c|}{ Avaliação da necessidade de novas áreas verdes públicas no Recife (\% por nota) } \\
\hline & 0 & 1 & 2 & 3 & 4 & 5 & 6 & 7 & 8 & 9 & 10 & \\
\hline Não Necessário & & 3 & & & & & & 3 & & & 94 & Necessário \\
\hline $\begin{array}{c}\text { Não necessita aumento } \\
\text { das áreas verdes }\end{array}$ & & 3 & & & & & & & 3 & 3 & 91 & $\begin{array}{c}\text { Necessita aumento } \\
\text { das áreas verdes }\end{array}$ \\
\hline $\begin{array}{c}\text { Implantar em locais com } \\
\text { poucas áreas verdes }\end{array}$ & 9 & 3 & & & & 3 & & 6 & 9 & 12 & 58 & $\begin{array}{c}\text { Distribuir por toda a } \\
\text { cidade }\end{array}$ \\
\hline $\begin{array}{c}\text { Novas áreas verdes não } \\
\text { serão visitadas }\end{array}$ & & & & 3 & & 3 & & & 3 & 9 & 82 & $\begin{array}{c}\text { Novas áreas verdes } \\
\text { serão visitadas }\end{array}$ \\
\hline $\begin{array}{c}\text { Não melhoram o bem- } \\
\text { estar da população }\end{array}$ & & & & & & & 9 & & & & 91 & $\begin{array}{c}\text { Melhoram o bem } \\
\text { estar da população }\end{array}$ \\
\hline $\begin{array}{c}\text { Vai repelir atividades } \\
\text { econômicas }\end{array}$ & 3 & 6 & & & & & & 6 & 9 & 3 & 73 & $\begin{array}{c}\text { Vai atrair atividades } \\
\text { econômicas }\end{array}$ \\
\hline $\begin{array}{c}\text { Não aumentará o valor } \\
\text { dos imóveis ao seu redor }\end{array}$ & 6 & & & & 3 & & & 3 & 9 & 6 & 73 & $\begin{array}{c}\text { Aumentará o valor } \\
\text { dos imóveis ao seu } \\
\text { redor }\end{array}$ \\
\hline
\end{tabular}

Os resultados da questão seguinte mostram um interesse geral na melhoria das áreas verdes públicas. $100 \%$ dos entrevistados responderam que as autoridades públicas competentes devem designar verbas para a manutenção das áreas verdes públicas existentes, 100\% também acham que devem ser investidos recursos para a criação de novas áreas. Na última questão, $24 \%$ dos entrevistados acham que as áreas verdes devem permanecer como estão e 76\% acham que as mesmas não devem passar por níveis diferentes de de melhorias, com as respostas variando entre as notas 8 a 10 (tabela 02).

Tabela 2. Opinião dos entrevistados em relação aos gastos com as áreas verdes

\begin{tabular}{|c|c|c|c|c|c|c|c|c|c|c|c|c|}
\hline & 0 & 1 & 2 & 3 & 4 & 5 & 6 & 7 & 8 & 9 & 10 & \\
\hline $\begin{array}{l}\text { A cidade deve gastar } \\
\text { menos dinheiro com a } \\
\text { manutenção }\end{array}$ & & & & & & & & & & & 100 & $\begin{array}{c}\text { A cidade deve gastar } \\
\text { mais dinheiro com a } \\
\text { manutenção }\end{array}$ \\
\hline $\begin{array}{l}\text { A cidade deve gastar } \\
\text { menos dinheiro com a } \\
\text { criação de novas áreas }\end{array}$ & & & & & & & & & & & 100 & $\begin{array}{l}\text { A cidade deve gastar } \\
\text { mais dinheiro com a } \\
\text { criação de novas } \\
\text { áreas }\end{array}$ \\
\hline $\begin{array}{l}\text { A cidade deve gastar } \\
\text { menos dinheiro com a } \\
\text { manutenção }\end{array}$ & 24 & & & & & & & & 14 & 30 & 32 & $\begin{array}{l}\text { A cidade deve gastar } \\
\text { mais dinheiro com a } \\
\text { manutenção }\end{array}$ \\
\hline
\end{tabular}

Em seguida os usuários foram indagados quanto à sua percepção de aspectos relativos à acessibilidade da área verde, estado e estimativa de custo de sua manutenção, grau de apreciação da área pela população, impacto econômico, perspectivas de diversificação dos seus usos e por fim aspectos sociais gerais dos frequentadores. Ao contrário dos outros temas, as respostas a esta seção do questionário apresentaram uma 
distribuição mais homogênea em relação aos valores das notas, demonstrando um grau de maior personalismo na forma que os diversos aspectos relativos ao uso das áreas verdes são percebidos por cada entrevistado. As respostas obtidas foram tabuladas em porcentagem de respostas na tabela abaixo (Tabela 03).

Tabela 3. Avaliação da acessibilidade, conservação e percepção dos aspectos sócio-econômicos das áreas verdes públicas do Recife

\begin{tabular}{|c|c|c|c|c|c|c|c|c|c|c|c|c|}
\hline \multicolumn{13}{|c|}{$\begin{array}{l}\text { Avaliação geral da área verde: acessibilidade, conservação, aspectos sócio-econômicos } \\
\qquad \text { (\% por nota) }\end{array}$} \\
\hline & 0 & 1 & 2 & 3 & 4 & 5 & 6 & 7 & 8 & 9 & 10 & \\
\hline Não é acessível & 3 & & & 6 & & 12 & & 3 & 21 & 6 & 51 & É muito acessível \\
\hline É mal cuidado & 6 & 6 & & & & 18 & 3 & 12 & 27 & 6 & 22 & É bem cuidado \\
\hline $\begin{array}{l}\text { Baixo custo de } \\
\text { manutenção }\end{array}$ & 9 & & & 9 & 3 & 9 & 18 & 21 & 18 & 9 & 4 & $\begin{array}{l}\text { Alto custo de } \\
\text { manutenção }\end{array}$ \\
\hline $\begin{array}{l}\text { Pouco visitado pela } \\
\text { população }\end{array}$ & 3 & 6 & & 3 & 3 & 6 & & 9 & 3 & 6 & 61 & $\begin{array}{l}\text { Muito visitado pela } \\
\text { população }\end{array}$ \\
\hline $\begin{array}{l}\text { Pouco apreciado pela } \\
\text { população }\end{array}$ & 6 & & & & 3 & 3 & & 12 & 6 & 9 & 61 & $\begin{array}{l}\text { Muito apreciado pela } \\
\text { população }\end{array}$ \\
\hline $\begin{array}{l}\text { Repele atividades } \\
\text { econômicas }\end{array}$ & 3 & & & 3 & & 9 & 12 & 6 & 15 & 6 & 46 & $\begin{array}{l}\text { Atrai atividades } \\
\text { econômicas }\end{array}$ \\
\hline $\begin{array}{l}\text { Pouca atividade } \\
\text { econômica ao redor }\end{array}$ & 9 & & & 6 & 9 & 6 & 6 & 12 & 9 & 9 & 34 & $\begin{array}{l}\text { Muita atividade } \\
\text { econômica ao redor }\end{array}$ \\
\hline $\begin{array}{c}\text { Número adequado de } \\
\text { atrações }\end{array}$ & 3 & & & & & & & 3 & 12 & 9 & 73 & $\begin{array}{c}\text { Necessita de novas } \\
\text { atrações }\end{array}$ \\
\hline $\begin{array}{l}\text { Frequentadores de baixa } \\
\text { renda }\end{array}$ & 15 & & 3 & 9 & 12 & 15 & 18 & 6 & 12 & 3 & 7 & $\begin{array}{l}\text { Frequentadores de } \\
\text { alta renda }\end{array}$ \\
\hline $\begin{array}{c}\text { Predomínio da classe } \\
\text { trabalhadora }\end{array}$ & 15 & 6 & 12 & 6 & 12 & 21 & 15 & 6 & 3 & & 4 & $\begin{array}{l}\text { Predomínio da classe } \\
\text { alta }\end{array}$ \\
\hline Pessoas solteiras & 6 & 3 & 3 & 3 & 3 & 24 & 6 & 9 & 15 & 3 & 25 & Famílias \\
\hline
\end{tabular}

A última pergunta da entrevista foi direcionada à prospecção e implantação de novas áreas verdes públicas nas proximidades do local da entrevista. Os resultados apontaram para percepção em geral benéfica em relação aos itens propostos, com destaque para a questão do bem-estar para a população, como $88 \%$ das respostas conferidas à nota máxima (10). Em semelhança a outros itens anteriores, a questão de custo de manutenção é a que apresenta menos consenso, com uma distribuição menos concentrada das notas. Mais uma vez a valorização imobiliária aparece como um cenário percebido como provável, com $73 \%$ dos entrevistados atribuindo nota máxima a este item (Tabela 04).

Tabela 4. Percepções acerca da implementação de uma nova área verde no local da entrevista 


\begin{tabular}{|c|c|c|c|c|c|c|c|c|c|c|c|c|}
\hline \multicolumn{13}{|c|}{ Avaliação sobre a implantação de uma nova área verde no local da entrevista (\% por nota) } \\
\hline & 0 & 1 & 2 & 3 & 4 & 5 & 6 & 7 & 8 & 9 & 10 & \\
\hline Não é necessário & 27 & & 3 & 6 & 6 & 6 & & & & 3 & 49 & É necessário \\
\hline $\begin{array}{l}\text { Custo de manutenção } \\
\text { seria baixo }\end{array}$ & 6 & & 6 & & & 21 & 12 & 3 & 15 & 9 & 28 & $\begin{array}{c}\text { Custo de manutenção } \\
\text { seria alto }\end{array}$ \\
\hline $\begin{array}{l}\text { Não seria utilizado pela } \\
\text { população }\end{array}$ & & & & & & 3 & & 9 & 3 & 9 & 76 & $\begin{array}{l}\text { Seria muito utilizado } \\
\text { pela população }\end{array}$ \\
\hline $\begin{array}{l}\text { Não faria diferença para o } \\
\text { bem-estar da população }\end{array}$ & & & & & & & & 3 & 6 & 3 & 88 & $\begin{array}{c}\text { Faria diferença para o } \\
\text { bem-estar da } \\
\text { população }\end{array}$ \\
\hline $\begin{array}{l}\text { Repeliria atividades } \\
\text { econômicas }\end{array}$ & 6 & 3 & 3 & & & 9 & 3 & & 9 & 9 & 58 & $\begin{array}{l}\text { Atrairia atividades } \\
\text { economicas }\end{array}$ \\
\hline $\begin{array}{l}\text { Não interferiria nos } \\
\text { preços dos imóveis }\end{array}$ & 9 & & & & & & 6 & 3 & 3 & 6 & 73 & $\begin{array}{l}\text { Aumentaria o preço } \\
\text { dos imóveis }\end{array}$ \\
\hline
\end{tabular}

Quando considerados em relação às respostas dadas em certas áreas verdes em específico, os resultados apontam para particularidades decorrentes do perfil sócio-econômico dos usuários e do próprio contexto em que a área se insere dentro da cidade. Assim, no Parque da Jaqueira, situado na área nobre da zona norte do Recife, com valor do $\mathrm{m}^{2}$ dos imóveis residenciais equivalentes à avenida beira mar do bairro de Boa Viagem (área nobre da zona sul), 100\% dos entrevistados atribuem importância máxima à presença do parque à existência do comércio dos arredores, caracterizado por galerias de lojas de alto padrão.

Em relação à prospeç̧ão de uma nova área verde nas proximidades ainda no Parque da Jaqueira, 100\% dos frequentadores deste parque, acham que a presença de uma nova área verde traria uma valoração ainda maior dos valores imobiliários para os imóveis situados nos arredores.

Por outro lado, em uma área de baixa renda no sudoeste da cidade do Recife, a análise dos dados referentes ao Parque do Jiquiá, bairro do Jiquiá, mostrou que a perspectiva da população do entorno do parque está dividida entre a transformação do mesmo em uma área de utilização para a população e a criação de uma nova área, um novo parque que atendesse às necessidades das famílias para esporte e lazer, visto que a área atual passa um estado de abandono. Assim, 50\% dos entrevistados acham necessária a criação de nova área verde nas proximidades, 50\% acham que o parque existente deve ser recuperado e transformado para uso da população. No entanto, $100 \%$ dos entrevistados acham que uma nova área verde nos arredores seria utilizada pela população e $100 \%$ também acham que faria diferença para o seu bem-estar.

Por fim, a pesquisa nos mostra a desigualdade com que parques e áreas verdes públicas no Recife são tratadas por parte dos órgãos públicos competentes, além de apontar para o sentimento dos seus usuários em relação à situação atual dessas áreas no tocante à sua manutenção, preservação e oferta pública de lazer. Os resultados mostram que $78 \%$ da população percebem que a quantidade de áreas verdes existentes é suficiente para a cidade, no entanto resta nítido que o estado de conservação, acessibilidade e perspectiva de melhorias é ainda bastante desigual nos diversos bairros e unidades ambientais que integram o município. 


\section{CONCLUSÕES}

Esta pesquisa apoiou-se na tipologia ambiental proposta por Souza, Corrêa e Silva (2017, p. 147-168), sobrepondo a essa os parques e áreas verdes apontados pela prefeitura da Cidade do Recife. Inicialmente, constatou-se que essas não abrangem todas as unidades ambientais do município, nem as regiões de maior concentração populacional.

Parques e Praças, dotados de segurança pública são utilizados pela população citadina para variadas funções sociais, no entanto, áreas que ofereçam esses equipamentos e qualidade ambiental estão praticamente restritas aos bairros que concentram as maiores rendas per capita do Recife. Esta disparidade entre bairros deve-se à falha ou mesmo falta de planejamento, comum, no desenvolvimento das grandes metrópoles brasileiras.

Desta forma, as áreas verdes urbanas do Recife além de não se encontrarem representadas em todas as unidades ambientais do município, não satisfazem plenamente à população citadina. Os três parques em melhores condições de uso abordados por essa pesquisa estão inseridos em áreas de alta renda e geograficamente não estão no entorno imediato do cotidiano da população de renda mais baixa, majoritariamente residente em áreas de morro ou alagadiças desprovidas de áreas verdes públicas e seus benefícios.

Apesar de ser compreendido pelas variadas normativas que regem o planejamento urbano que a população como um todo precisa de acesso à qualidade ambiental, e que este bem é fundamental para uma boa qualidade de vida, na prática a cidade continua negando esse recurso aos cidadãos de baixa renda. Cabe ao poder municipal prever, criar e manter adequadamente áreas livres de construção para que apesar da expansão das cidades, o desenvolvimento urbano reserve locais agradáveis que tanto gerem bem-estar para a população quanto promovam a manutenção da qualidade ambiental de maneira uniforme no espaço urbano.

Por fim, a pesquisa nos mostra a desigualdade com que parques e áreas verdes públicas no Recife são tratadas por parte dos órgãos públicos competentes, além de apontar para o sentimento dos seus usuários em relação à situação atual dessas áreas no tocante à sua manutenção, preservação e oferta pública de lazer. Os resultados mostram que $78 \%$ da população percebem que a quantidade de áreas verdes existentes é suficiente para a cidade, no entanto resta nítido que o estado de conservação, acessibilidade e perspectiva de melhorias é ainda bastante desigual nos diversos bairros e unidades ambientais que integram o município. 


\section{REFERÊNCIAS}

ARNBERGER, A. et all. Urban Sprawl and Protected Areas: how effective are buffer zones in reducing recreation impacts on an urban national park?. In: 5th SYMPOSIUM FOR RESEARCH IN PROTECTED AREAS, 5, 2013, Austria. Sustainability, Austria, 2013, p. 21-25.

BRASIL. Lei 10.257 de 10 de julho de 2001: Regulamenta os artigos 182 e 183 da Constituição Federal, estabelece diretrizes gerais da política urbana e dá outras providências. Brasília: Congresso Nacional, 2001. Disponível em:

http://www.planalto.gov.br/ccivil_03/leis/leis_2001/l10257.htm, Acesso em: 10 janeiro 2020.

BRASIL. Lei 9.985 de 18 de julho de 2000: Regulamenta o art. 225, § 1, incisos I, II, III e VII da Constituição Federal, institui o Sistema Nacional de Unidades de Conservação da Natureza e dá outras providências. Brasília: Congresso Nacional, 2000. Disponível em: http://www.planalto.gov.br/ccivil_03/leis/leis_2001/I10257.htm, Acesso em: 20 janeiro 2020.

CORRÊA, Antônio Carlos de Barros. Contribuição à análise do Recife como um Geossistema Urbano. Revista de Geografia da UFPE, Recife, v. 23, n.3. p.86-102, 2006.

CHRISTOFOLETTI, Antonio. Modelagem de sistemas ambientais. 1. São Paulo. Ed. - São Paulo: Edgard Blucher, 1999.

FONSECA, Drielly Naamma, CORRÊA, Antonio Carlos de Barros; SILVA, Adriana Cassiano. Compartimentação geomorfológica da região metropolitana do recife (RMR) a partir da análise morfoestrutural. Geo UERJ, Rio de Janeiro, n. 29, p. 201-219, 2016

GRAY, Murrey. Geodiversity: valuing and conserving abiotic nature. Wiley Blackwell: University of London, 2004.

JORNAL DO COMERCIO. Prefeitura apresenta projetos para o Parque do Jiquiá. 07.12.2012. Disponível em: https://jconline.ne10.uol.com.br/canal/cidades/noticia.Acesso em: 05 janeiro 2020

JORNAL DO COMERCIO. Proposta para o Parque do Jiquiá será apresentada à sociedade. 13.07.2017. Disponível em: https://jconline.ne10.uol.com.br/.cesso em: 10 janeiro 2020

LEE, Yung Chang, KIM, Keum-Ho. Attitudes of Citizens towards Urban Parks and Green Spaces for Urban Sustainability: The Case of Gyeongsan City, Republic of Korea. Sustainability 7, p. 240-254, 2015

MADUREIRA, Helena et all. Preferences for Urban Green Space Characteristics: A Comparative Study in Three Portuguese Cities. Environments, 2018, p. 5-23, 2018.

OMS - Organização Mundial de Saúde - WHOQOL (The World Health Organization Quality of Life)-100, The 100 questions with response scale, disponível em :https://www.who.int/mental_health/publications/whoqol/en/.- Acesso em: 15 junho 2018.

PREFEITURA DA CIDADE DO RECIFE. Informações Parques Da Cidade Do Recife. Disponível em: https://visit.recife.br/. Acesso em: 20 dezembro 2019

RECIFE. Lei no 17.511/2008: Promove a revisão do Plano Diretor da Cidade do Recife. Recife, 2008. Disponível em: https://leismunicipais.com.br/. Acesso em: 10 setembro 2019

SECRETARIA DE PLANEJAMENTO DA CIDADE DO RECIFE. Estatuto da Cidade. Disponível em: www.recife.gov.pe.br/planodiretor. Acesso em: 05 outubro 2019

SECRETARIA DE MEIO AMBIENTE E SUSTENTABILIDADE. Parque dos Manguezais inicia processo de elaboração de plano de manejo. 24.08.2018. Disponível em: http://meioambiente.recife.pe.gov.br/ noticias/parque-dos-manguezais-. Acesso em: 10 dezembro 2019

SOUZA, Joazadaque Lucena de; CORRÊA, Antônio Carlos de Barros; SILVA, Oswaldo Girão. Compartimentação Geomorfológica da Planície do Recife, Pernambuco, Brasil. Revista de Geografia (Recife), Recife, v.34, n. 1, p. 147-168, 2017. 